\title{
OPTIMASI PEMBAGIAN BEBAN PADA TURBIN GAS BLOK 1 DAN BLOK 3 PLTGU PT. PJB UP GRESIK MENGGUNAKAN METODE ITERASI LAMBDA BERDASARKAN BASE POINT AND PARTICIPATION FACTORS
}

\author{
Ery Fuji Risnawati ${ }^{1, a)}$ dan Nurissaidah Ulinnuha ${ }^{1, b)}$ \\ ${ }^{1}$ Universitas Islam Negeri Sunan Ampel Surabaya \\ a)eryfujir123@gmail.com \\ b) nuris.ulinnuha@uinsby.ac.id
}

\begin{abstract}
Abstrak
Pengoperasian sistem tenaga listrik yang baik dibutuhkan pada sistem pembangkitan untuk mendapatkan biaya operasi yang ekonomis dan pembagian beban yang optimal. Pengoptimalan pembangkitan dapat dilakukan dengan pembagian pembebanan atau economic dispatch untuk mendapatkan daya yang maksimum dengan biaya yang minimum. Metode yang dipakai yaitu iterasi lambda berdasarkan base point and participation factors untuk pembagian beban secara optimal. Pada penelitian ini, metode iterasi lambda berdasarkan base point and participation factors memberikan pembagian beban yang lebih optimal dan biaya operasi lebih hemat dibandingkan sebelumnya. Hasil pembagian beban pada kasus di PLTGU PT PJB UP Gresik yang lebih optimal yaitu turbin gas 1.3 pada Blok 1 dan turbin gas 3.3 pada Blok 3. Pada Blok 1, rata-rata daya yang dibangkitkan turbin gas 1.3 95,449 MW. Pada Blok 3, rata-rata daya yang mampu dibangkitkan turbin gas 3.3 89,205 MW. Biaya yang dihemat setelah optimasi diperoleh selisih pada Blok 1 sebesar Rp. 395.955.074,64 dan Blok 3 sebesar Rp. 565.297.532,00.
\end{abstract}

Kata kunci: Sistem Tenaga Listrik, Optimasi, Iterasi Lambda, Base Point and Participation Factors

\begin{abstract}
The operation of a good electric power system is needed in the generation system to obtain economical operating costs and optimal load sharing. Optimization of generation can be done by sharing the burden or economic dispatch to get maximum power with minimum costs. The method used is the lambda iteration based on the base point and participation factors for optimal load sharing. In this study, the lambda iteration method based on the base point and participation factors provide more optimal load sharing and lower operating costs than before. The optimal result of load sharing in the case of PT PJB UP Gresik PLTGU is the gas turbine 1.3 in Block 1 and the gas turbine 3.3 in Block 3. In Block 1, the average power generated by the 1.3 turbine gas turbine is 95,449 MW. In Block 3, the average power
\end{abstract}


capable of generating gas turbines is $3.389,205 \mathrm{MW}$. The cost saved after optimization is obtained in the difference in Block 1 of Rp. 395.955.074,64 and Block 3 of Rp. 565.297.532,00.

Keywords: Electric Power System, Optimation, Lambda Iteration, Base Point and Participation Factors

\section{Pendahuluan}

Energi listrik merupakan salah satu energi yang tidak terpisahkan dalam kehidupan saat ini. Kehidupan sehari-hari hampir semua membutuhkan energi listrik sebagai penunjang, seperti pada dunia industri, dunia pendidikan, rumah tangga, tempat hiburan, layanan umum dan lainnya [1]. Kebutuhan energi listrik semakin meningkat selaras dengan perkembangan teknologi yang semakin pesat. Kebutuhan yang semakin meningkat berakibat pada permintaan produksi daya listrik. Semakin besar permintaan dari masyarakat, penyediaan daya listrik akan bertambah besar [2].

Untuk memenuhi kebutuhan yang semakin meningkat, unit pembangkit listrik akan mengoptimalkan produksi agar dapat memenuhi permintaan dari masyarakat. Unit pembangkit listrik dapat memproduksi sesuai kapasitas atau sesuai permintaan yang ada. Permintaan semakin tinggi, semakin tinggi juga produksi daya yang harus dihasilkan dari pembangkit. Proses pembangkitan yang tinggi berpengaruh dengan biaya bahan bakar yang digunakan. Semakin besar daya yang ingin dihasilkan, maka semakin besar juga biaya bahan bakar yang digunakan.

Setiap unit pembangkit memiliki karakteristik yang berbeda-beda mengenai biaya produksi. Biaya bahan bakar yang besar berpengaruh pada biaya operasi pembangkit listrik menjadi tidak ekonomis. Pengoptimalan pembangkitan dapat dilakukan dengan pembagian pembebanan atau economic dispatch untuk mendapatkan daya yang maksimum dengan biaya yang minimum. Economic dispatch adalah pembagian pembebanan pada unit-unit pembangkit secara optimal serta ekonomis pada harga beban tertentu [3].

Pada penelitian sebelumnya yang dilakukan oleh Kartika Ika Putri (2017) menunjukkan bahwa economic dispatch unit-unit pembangkit thermal dalam sistem kelistrikan Sumatera Barat dengan metode iterasi lambda memberikan penjadwalan yang efisien dan efektif dalam menekan biaya operasi pembangkit listrik dibandingkan tanpa menggunakan economic dispatch [4]. Hana Nabila(2017) meneliti analisis economic dispatch pada PLTU Sektor Bukit Asam menggunakan metode iterasi lambda dan dynamic programming yang menghemat penggunaan bahan bakar sebesar 4.621,94 ton, hal ini menunjukkan bahwa pembagian beban yang optimal dapat menghemat konsumsi bahan bakar [5]. Metode yang digunakan dalam permasalahan economic dispatch pada penelitian ini adalah metode iterasi lambda yang berdasarkan pada base point and participations factors untuk mendapatkan pembagian beban yang optimal dengan penghematan biaya bahan bakar.

\section{Metode}

\section{Pembangkit Listrik Tenaga Gas dan Uap (PLTGU)}

PLTGU adalah pembangkit listrik tenaga termal yang memanfaatkan tenaga gas dan uap sebagai hasil combine system dari Pembangkit Listrik Tenaga Gas (PLTG) dan Pembangkit Listrik Tenaga Uap (PLTU). PLTGU memiliki dua macam operasi yaitu open cycle dan combined cycle. Operasi open cycle 
merupakan sistem operasi dimana gas buang gas turbin dibuang langsung dan tidak dimanfaatkan, sedangkan combined cycle merupakan sistem yang memanfaatkan gas buang gas turbin untuk proses pemanasan air menjadi uap kering yang digunakan untuk menggerakkan turbin uap [6]. PLTGU memanfaatkan pembakaran bahan bakar untuk menggerakkan turbin gas yang dikopel langsung dengan generator menggunakan satu poros, hasil sisa gas buang dari turbin gas digunakan untuk memanaskan air pada pipa-pipa yang ada di dalam Heat Recovery Steam Generator (HRSG) untuk merubah fase air menjadi fase uap. Hasil uap tersebut digunakan untuk menggerakkan turbin uap yang terhubung dengan generator sehingga dapat menghasilkan listrik. PLTGU Unit Pembangkitan Gresik memiliki kapasitas daya produksi $1.500 \mathrm{MW}$ dengan tiga blok masing-masing dengan kapasitas daya 500W. Masing-masing blok memiliki tiga unit gas turbin, tiga HRSG, dan satu turbin uap.

\section{Karakteristik Input-Output Pembangkit}

Fungsi dasar pada perhitungan biaya operasi ekonomis pada pembangkit termal berdasarkan karakteristik input-output penggunaan bahan bakar pada unit pembangkit. Karakteristik input-output pembangkit termal merepresentasikan hubungan antara masukan bahan bakar unit pembangkit yang dapat dinyatakan dalam satuan $\mathrm{kkal} / \mathrm{jam}, \mathrm{KNm}^{3} / \mathrm{jam}, \mathrm{MBTU} / \mathrm{jam}$, dan \$/jam terhadap keluaran daya dalam satuan $\mathrm{MW}$ sebagai input dan output menyatakan daya keluaran listrik yang dihasilkan oleh pembangkit. Biaya proses pembangkitan merupakan perkalian dari biaya (\$) kalor yang dimiliki oleh bahan bakar yang digunakan dengan kebutuhan kalor tiap jam dari generator $(b t u / h)$.

Karakteristik input-output dapat direpresentasikan dalam persamaan yang merupakan pendekatan dari biaya bahan bakar yang masuk terhadap daya keluaran yang diperoleh dari generator dapat dihasilkan dengan beberapa cara yaitu:

a. Percobaan empiris mengenai efisiensi dari pembangkit.

b. Data historis mengenai operasi unit generator.

c. Data desain generator dari pabrik pembuat generator tersebut.

Berikut istilah-istilah yang digunakan dalam mendefinisikan karakteristik dari unit pembangkit:

a. $\quad H$ : Besaran panas sebagai input unit pembangkit (Mmbtu/jam)

b. $F$ : Besaran biaya input unit pembangkit (Harga bahan bakar $\times \mathrm{H})=\$ /$ jam

Pemodelan fungsi mengunakan polinomial orde dua untuk mendapatkan pendekatan hubungan antara input bahan bakar terhadap output yang dihasilkan pembangkit sehingga dapat dituliskan dengan Persamaan 1:

$$
H_{i}=a_{i}+\beta_{i} P_{i}+\gamma_{i} P_{i}^{2}
$$

Nilai konstanta input-output pembangkit didapatkan dengan menggunakan metode least square (kuadrat terkecil) polinom orde dua. Berdasarkan $n$ data daya keluaran $P$ dan jumlah bahan bakar $H$, konstanta persamaan didapatkan dari penyelesaian Persamaan 5.

$$
\begin{aligned}
& N a+\beta \sum P_{i}+\gamma \sum P_{i}^{2}=\sum H_{i} \\
& a \sum P_{i}+\beta \sum P_{i}^{2}+\gamma \sum P_{i}^{3}=\sum P_{i} H_{i} \\
& a \sum P_{i}^{2}+\beta \sum P_{i}^{3}+\gamma \sum P_{i}^{4}=\sum P_{i}^{2} H
\end{aligned}
$$


Diubah dalam bentuk matriks menjadi:

$$
\left(\begin{array}{ccc}
n & \sum P_{i} & \sum P_{i}^{2} \\
\sum P_{i} & \sum P_{i}^{2} & \sum P_{i}^{3} \\
\sum P_{i}^{2} & \sum P_{i}^{3} & \sum P_{i}^{4}
\end{array}\right)\left(\begin{array}{l}
a \\
\beta \\
\gamma
\end{array}\right)=\left(\begin{array}{c}
\sum H_{i} \\
\sum P_{i} H_{i} \\
\sum P_{i}^{2} H_{i}
\end{array}\right)
$$

Bagian utama dalam biaya operasional adalah biaya bahan bakar (fuelcost). Pada umumnya fuelcost dapat direpresentasikan dalam Persamaan 6 berikut:

$$
\text { fuelcost }=\frac{R}{M b t u}
$$

Hubungan nilai fuelcost terhadap fungsi biaya dapat dinyatakan Persamaan 7.

$$
F_{i}=H_{i} \times \text { fuelcost } i
$$

\section{Economic Dispatch}

Optimasi operasi pembangkit dalam dilakukan dengan penjadwalan pembangkit dengan tujuan meminimalkan biaya operasi pembangkitan [7]. Economic dispatch adalah pembagian pembebanan setiap unit pembangkit yang dapat memenuhi kebutuhan beban dengan biaya yang optimum atau untuk mencari nilai optimum dari output daya dari kombinasi unit pembangkit yang memiliki tujuan untuk meminimalkan total biaya pembangkitan [3]. Pengoptimalan permasalahan economic dispatch perlu dilakukan untuk memperkirakan jangka panjang dalam sistem tenaga listrik, perkiraan biaya operasi, dan pemodelan manajemen operasi pembangkit.

\section{Iterasi Lambda}

Metode iterasi lambda merupakan salah satu metode untuk menyelesaikan permasalahan economic dispatch. Pada metode ini, nilai lambda pertama akan ditentukan terlebih dahulu, nilai lambda awal diperoleh dari koeifisien $\beta$ terbesar diantara fungsi karakteristik biaya bahan bakar yang sudah diperoleh pada Persamaan 7. Nilai lambda yang pertama belum tentu hasil yang optimal. Iterasi nilai lambda $(\lambda)$ dilakukan hingga memenuhi syarat nilai $\Delta P_{N}<0,001$.

$$
\Delta \lambda_{n}=\frac{\Delta P_{N}}{\frac{1}{F^{\prime \prime}}}
$$

Nilai lambda akan digunakan untuk menghitung nilai $P_{i}$ dengan Persamaan 9.

$$
P_{i}=\frac{\lambda-\beta}{2 \gamma}
$$

Ketika nilai total dari daya $\mathrm{P}_{1}+\mathrm{P}_{2}+\ldots . \mathrm{P}_{\mathrm{i}}<$ target maka nilai $\lambda$ untuk iterasi selanjutnya bertambah besar dari nilai $\lambda$ sebelumnya. Apabila nilai total dari daya $P_{1}+P_{2}+\ldots . P_{i}>$ target maka sebaliknya nilai $\lambda$ untuk iterasi selanjutnya akan lebih kecil daripada nilai $\lambda$ sebelumnya. Iterasi akan berhenti sampai hasil dari $\mathrm{P}_{1}$ $+\mathrm{P}_{2}+\ldots . \mathrm{P}_{\mathrm{i}}=\mathrm{P}$ target $[8]$. 


\section{Base Point and Participation Factors}

Metode ini menyelesaikan economic dispatch secara berulang untuk mendapatkan penjadwalan yang optimal, yaitu dengan memindahkan unit pembangkit dari satu jadwal yang optimal secara ekonomis ke unit yang lain akibat perubahan beban yang kecil. Turunan pertama dari $\mathrm{F}^{\prime}$ dan turunan kedua dari $\mathrm{F}^{\prime \prime}$ ada dengan perubahan beban sebesar $\Delta P_{i}$, dan perubahan incrementasl cost dari $\lambda^{0}$ ke $\lambda^{0}+\Delta \lambda$.

$$
\Delta \lambda_{i}=\Delta \lambda \cong F^{\prime \prime}{ }_{i}\left(\begin{array}{l}
0 \\
i
\end{array}\right) \Delta P_{i}
$$

Dengan setiap unit $n$ pada sistem, didapatkan Persamaan 11:

$$
\Delta P_{N}=\Delta P_{D}-\sum P_{i}^{k}
$$

dimana $k=$ jam operasi

Total perubahan beban $\left(\mathrm{P}_{\mathrm{D}}\right)$ pada masing-masing unit pembangkit, dapat dituliskan pada Persamaan 13.

$$
\begin{aligned}
& \Delta P_{D}=\Delta P_{1}+\Delta P_{2}+\Delta P_{3}+\cdots+\Delta P_{N} \\
& \Delta P_{D}=\sum_{i} \frac{1}{F^{\prime \prime}}
\end{aligned}
$$

Berdasarkan persamaan yang ada di atas, dapat digunakan untuk menentukan persamaan participation factors untuk setiap unit pembangkit sehingga diperoleh Persamaan 14.

$$
\left(\frac{\Delta P_{i}}{\Delta P_{D}}\right)=\frac{\left(\frac{1}{F_{i}^{n}}\right)}{\Sigma\left(\frac{1}{F_{i}}\right)}
$$

Untuk mengetahui nilai pembagian beban yang optimal dihitung menggunakan Persamaan 15 dan 16.

$$
\begin{aligned}
& \Delta P_{D i}=\text { total daya jam } i+1-\text { total daya jam } i \\
& P_{\text {inew }}=P_{\text {base }}+\left(\frac{\Delta P_{i}}{\Delta P_{D}}\right) \Delta P_{D i}
\end{aligned}
$$

\section{Hasil dan Diskusi}

Berdasarkan data yang didapatkan, bahwa jenis bahan bakar yang digunakan dalam proses produksi adalah bahan bakar gas dengan nilai GHV (Gross Heating Value) sebesar 1052.898 Btu/Scf dengan asumsi harga $7 \$ / M m b t u$. Data penggunaan gas selama produksi atau aliran gas yang dipakai dinyatakan dengan satuan $\mathrm{KNm}^{3} / \mathrm{jam}$. Data dengan satuan $\mathrm{KNm}^{3} / \mathrm{jam}$ akan dikonversi dalam satuan Mmbtu untuk mengetahui biaya bahan bakar yang digunakan selama proses operasi.

Langkah pertama yang untuk mengonversi satuan $\mathrm{KNm}^{3} / \mathrm{jam}$ menjadi Mmbtu yaitu diubah dalam satuan MMSCF (Million Standard Cubic Feed), dimana $1 \mathrm{KNm}^{3} / \mathrm{jam}$ adalah 0,0373248 MMSCF. Setelah diketahui nilai MMSCF kemudian dikonversi dalam satuan Mmbtu (Million British Thermal Unit) dengan rumus pada Persamaan 17.

$$
M m b t u=M M S C F \times G H V
$$


Tabel 1. Data Perhitungan Turbin Gas 1.1 Blok 1 PLTGU

\begin{tabular}{lll}
\hline Daya (MW) & $\begin{array}{l}\text { Gas Flow } \\
(\mathrm{Mmbtu})\end{array}$ & Biaya (\$) \\
\hline 100,456 & 1186,79436 & 8307,56052 \\
95,437 & 1140,69138 & 7984,83967 \\
90,427 & 1094,37957 & 7660,65700 \\
85,456 & 1045,49992 & 7318,49945 \\
\hline
\end{tabular}

Tabel 2. Data Perhitungan Turbin Gas 3.1 Blok 3 PLTGU

\begin{tabular}{lll}
\hline Daya (MW) & $\begin{array}{l}\text { Gas Flow } \\
\text { (Mmbtu) }\end{array}$ & Biaya (\$) \\
\hline 100,473 & 1214,95145 & 8504,66015 \\
95,445 & 1166,71275 & 8166,98928 \\
90,459 & 1118,49572 & 7829,47005 \\
85,401 & 1034,84811 & 7243,93680 \\
\hline
\end{tabular}

Pada Tabel 1 dan 2 menunjukkan data pemakaian bahan bakar (gas flow) yang digunakan untuk membangkitkan masing-masing daya (MW) pada turbin gas 1.1 dan 1.2. Data pemakaian bahan bakar tersebut dapat digunakan untuk menghitung biaya yang dipakai saat proses pembangkitan.

Masing-masing Blok memiliki tiga gas turbin. Data tersebut digunakan untuk menentukan persamaan karakteristik input-output dari masing-masing turbin gas menggunakan polinomial orde dua. Pada turbin gas 1.1 Blok 1 diperoleh nilai $\alpha, \beta$, dan $\gamma$ sebagai berikut:

$$
\begin{aligned}
\left(\begin{array}{ccc}
n & \sum P_{i} & \sum P_{i}^{2} \\
\sum P_{i} & \sum P_{i}^{2} & \sum P_{i}^{3} \\
\sum P_{i}^{2} & \sum P_{i}^{3} & \sum P_{i}^{4}
\end{array}\right)\left(\begin{array}{l}
a \\
\beta \\
\gamma
\end{array}\right) & =\left(\begin{array}{c}
\sum H_{i} \\
\sum P_{i} H_{i} \\
\sum P_{i}^{2} H_{i}
\end{array}\right) \\
\left(\begin{array}{ccc}
31271,557 \\
471,776 & 34679,448 & 3246498,524 \\
34679,448 & 3246498,524 & 304991057,726
\end{array}\right)\left(\begin{array}{l}
a \\
\beta \\
\gamma
\end{array}\right) & =\left(\begin{array}{c}
312914735,377 \\
292649603,538 \\
272649
\end{array}\right) \\
\left(\begin{array}{l}
a \\
\beta \\
\gamma
\end{array}\right) & =\left(\begin{array}{c}
-238,943 \\
107,704 \\
-0,225
\end{array}\right)
\end{aligned}
$$

Persamaan karakeristik bahan bakar untuk masing-masing turbin gas dapat dilihat pada Tabel 3. Tabel 3 merupakan hasil dari perhitungan persamaan karakteristik input-output menggunakan polinomial orde dua sebagai berikut: 
Tabel 3. Karakteristik Turbin Blok 1 dan Blok 3 PLTGU

Turbin Gas

Turbin Gas 1.1

Turbin Gas 1.2

Turbin Gas 1.3

Turbin Gas 3.1

Turbin Gas 3.2

Turbin Gas 3.3

\section{Karakateristik Persamaan Biaya Bahan Bakar}

$$
\begin{gathered}
\mathrm{F}_{1}=-238,943+107,704 \mathrm{P}_{\mathrm{i}}+-0,225 \mathrm{P}_{\mathrm{i}}^{2} \\
\mathrm{~F}_{2}=919,623+82,856 \mathrm{P}_{\mathrm{i}}+-0,092 \mathrm{P}_{\mathrm{i}}^{2} \\
\mathrm{~F}_{3}=-20591,592+533,472 \mathrm{P}_{\mathrm{i}}+-2,428 \mathrm{P}_{\mathrm{i}}^{2} \\
\mathrm{~F}_{4}=-2216,920+154,987 \mathrm{P}_{\mathrm{i}}+-0,499 \mathrm{P}_{\mathrm{i}}^{2} \\
\mathrm{~F}_{5}=1182,034+77,220 \mathrm{P}_{\mathrm{i}}+-0,073 \mathrm{P}_{\mathrm{i}}^{2} \\
\mathrm{~F}_{6}=-2123,447+148,548 \mathrm{P}_{\mathrm{i}}+-0,457 \mathrm{P}_{\mathrm{i}}^{2}
\end{gathered}
$$

Pembagian beban dan perhitungan biaya bahan bakar dilakukan dengan menggunakan karakteristik input-output pembangkit, kapasitas maksimum dan minimum dari unit pembangkit termal, dan total beban $\left(P_{D}\right)$ pada setiap Blok 1 dan Blok 3.

Perhitungan secara manual dilakukan pada hari pertama bulan September 2018 pada jam 00.00 dengan total beban dari tiga gas turbin yang beroperasi di Blok 1 sebesar 296,6 MW.

$$
\begin{aligned}
& F_{1}=-238,943+107,704 P_{i}+-0,225 P_{i}^{2} \\
& F_{2}=919,623+82,856 P_{i}+-0,092 P_{i}^{2} \\
& F_{3}=-20591,592+533,472 P_{i}+-2,428 P_{i}^{2}
\end{aligned}
$$

Dimana batasan kapasitas minimum dan maksimum dari ketiga generator Blok 1 adalah $50 \mathrm{MW} \leq$ $\mathrm{P} \leq 100 \mathrm{MW}$. Berdasarkan dari fungsi karakteristik diperoleh nilai $\lambda$ awal yaitu $\$ 533,472 / \mathrm{MW}$.

$P_{1}^{(1)}=\frac{533,472-107,704}{2 \times(-0,225)}=-944,742$

$P_{2}^{(1)}=\frac{533,472-82,856}{2 \times(-0,092)}=-2438,156$

$P_{3}^{(1)}=\frac{533,472-533,472}{2 \times(-2,428)}=0$

Dengan $\mathrm{P}_{\mathrm{D}}=296,6 \mathrm{MW}$

$$
\begin{aligned}
\Delta P_{N} & =296,6-(-944,742-2438,156+0) \\
& =3679,498
\end{aligned}
$$

$\Delta \lambda_{1}=\frac{3679,498}{\frac{1}{2 \times(-0,225)}+\frac{1}{2 \times(-0,092)}+\frac{1}{2 \times(-2,428)}}$

$=-469,592$

Sehingga diperoleh lambda baru sebagai berikut:

$$
\begin{aligned}
\lambda_{2}= & \lambda \text { awal }+\Delta \lambda_{1} \\
& =533,472+(-469,592) \\
& =63,880
\end{aligned}
$$

Proses iterasi terbaru, 


$$
\begin{aligned}
P_{1}^{(2)} & =\frac{63,880-107,704}{2 \times(-0,225)}=97,242 \\
P_{2}^{(2)} & =\frac{63,880-82,856}{2 \times(-0,092)}=102,673 \\
P_{3}^{(2)} & =\frac{63,880-533,472}{2 \times(-2,428)}=96,684 \\
\Delta P_{N} & =296,6-(97,242+102,673+96,684) \\
& =0
\end{aligned}
$$

Jadi, dari perhitungan di atas diperoleh daya optimal masing-masing unit pembangkit yaitu:

$$
\begin{aligned}
& P_{1}=97,242 \\
& P_{2}=102,673 \\
& P_{3}=96,684
\end{aligned}
$$

Untuk menghitung daya optimal pada jam selanjutnya yaitu pada jam 02.00 dengan total beban $\left(P_{D}\right)$ sebesar 271,5 MW dan dilihat dari jam sebelumnya jam 00.00 dengan menggunakan metode base point and participation factors. Hasil daya yang optimal dengan metode iterasi lambda pada jam sebelumnya digunakan sebagai $\mathrm{P}_{\text {base. }}$.

$$
\begin{aligned}
P_{D}= & \frac{1}{2 \times(-0,225)}+\frac{1}{2 \times(-0,092)}+\frac{1}{2 \times(-2,428)} \\
= & -7,836 \\
\left(\frac{\Delta P_{1}}{\Delta P_{D}}\right) & =\frac{1}{2 \times(-0,225)} \\
& =0,283 \\
\left(\frac{\Delta P_{2}}{\Delta P_{D}}\right) & =\frac{1}{2 \times(-0,092)} \\
& =0,691 \\
\left(\frac{\Delta P_{3}}{\Delta P_{D}}\right) & =\frac{1}{2 \times(-2,428)} \\
& =0,026 \\
\Delta P_{D i}= & 271,5-2936 \\
= & -25,1 \mathrm{MW} \\
P_{\text {inew }} & =P_{\text {base }}+\left(\frac{\Delta P_{i}}{\Delta P_{D}}\right) \Delta P_{D i} \\
P_{1}= & 97,242+(0,283 \times(-25,1))=90,134 \\
P_{2}= & 102,673+(0,691 \times(-25,1))=85,341 \\
P_{3}= & 96,684+(0,026 \times(-25,1))=96,025
\end{aligned}
$$

Maka biaya bahan bakar dapat diperoleh dari hasil perkalian masing-masing daya unit pembangkit dengan persamaan biaya bahan bakar yang sudah didapatkan sebelumnya. $F_{1}=-238,943+107,704 P_{i}+-0,225 P_{i}^{2}$ 


$$
\begin{aligned}
& =-238,943+(107,704 \times 90,134)+\quad\left(-0,225 \times(90,134)^{2}\right) \\
& =U S D \text { 7.638,232/jam (Rp. 107.752.543,95/ jam) } \\
& F_{2}=919,623+82,856 P_{i}+-0,092 P_{i}^{2} \\
& =919,623+(82,856 \times 85,341)+\left(-0,092 \times(85,341)^{2}\right) \\
& =\text { USD 7317,591/jam(Rp.103.229.260,95/jam }) \\
& F_{3}=-20591,592+533,472 P_{i}+-2,428 P_{i}^{2} \\
& =-20591,592+(533,472 \times 96,025)+\left(-2,428 \times(96,025)^{2}\right) \\
& =\text { USD 8.242,437/jam(Rp.116.276.064,57/jam) }
\end{aligned}
$$

Perhitungan pada jam selanjutnya yaitu pada jam 02.00 dengan total beban $\left(P_{D}\right)$ sebesar $234 \mathrm{MW}$.

$$
\begin{aligned}
& \Delta P_{D i}=234-271,5 \\
& =-37,5 \mathrm{MW} \\
& P_{\text {inew }}=P_{\text {base }}+\left(\frac{\Delta P_{i}}{\Delta P_{D}}\right) \Delta P_{D i} \\
& P_{1}=90,134+(0,283 \times(-37,5))=79,515 \\
& P_{2}=85,341+(0,691 \times(-37,5))=59,446 \\
& P_{3}=96,025+(0,026 \times(-37,5))=95,039
\end{aligned}
$$

Diperoleh total biaya operasi pada jam 03.00 sebesar:

$F_{1}+F_{2}+F 3=97.344 .385,46+77.849 .444,21+115.310 .307,07$

$$
=\text { Rp. } 290.504 .136,74 / \mathrm{jam}
$$

Perhitungan yang sama dilakukan pada unit pembangkit di Blok 3. Hasil dari perbandingan ditampilkan pada Tabel 4, 5, dan 6.

Tabel 4. Hasil Optimasi Pada Blok 1

\begin{tabular}{lllllll}
\hline No & GT 1.1 & GT 1.2 & GT.13 & Total Daya & $\begin{array}{l}\text { Biaya } \\
\text { sebelum } \\
\text { optimasi (\$) }\end{array}$ & $\begin{array}{l}\text { Biaya } \\
\text { sesudah } \\
\text { optimasi (\$) }\end{array}$ \\
\hline 1 & 90,134 & 85,341 & 96,025 & 271,500 & $23.308,11$ & $23.198,261$ \\
2 & 79,515 & 59,446 & 95,039 & 234,000 & $20.889,35$ & $20.592,907$ \\
3 & 79,345 & 59,032 & 95,023 & 233,400 & $20.916,83$ & $20.549,762$ \\
4 & 80,903 & 62,829 & 95,168 & 238,900 & $21.054,26$ & $20.943,533$ \\
5 & 79,062 & 58,341 & 94,997 & 232,400 & $21.026,78$ & $20.477,753$ \\
6 & 79,713 & 59,929 & 95,058 & 234,700 & $21.136,72$ & $20.643,184$ \\
$\cdot$ & $\cdot$ & $\cdot$ & $\cdot$ & $\cdot$ & $\cdot$ & $\cdot$ \\
$\cdot$ & $\cdot$ & $\cdot$ & $\cdot$ & $\cdot$ & $\cdot$ & $\cdot$ \\
$\cdot$ & $\cdot$ & $\cdot$ & $\cdot$ & $\cdot$ & & $\cdot$ \\
167 & 83,083 & 68,147 & 95,370 & 246,600 & $21.549,01$ & $21.488,326$ \\
Jumlah (\$) & & & & & 3.648 .819 .18 & $3.620 .751,19$
\end{tabular}


Rata-rata/jam (\$)

Rata-rata selisih biaya setiap jam (\$)
$21.849,22$

$21.681,14$

168,07

Tabel 4 menunjukan hasil optimasi dari blok 1, dari hasil optimasi tersebut biaya sesudah optimasi dengan melakukan pembagian beban pada masing-masing gas turbin lebih hemat dibandingkan dengan biaya sebelum dilakukan optimasi pembagian beban pada gas turbin. Gas turbin 1.3 pada blok 1 lebih hemat dibandingkan dengan gas turbin lainnya karena menghasilkan rata-rata beban yang paling optimum dengan biaya yang lebih sedikit. Rata-rata selisih biaya setiap jam pada blok 1 sebesar $\$ 168,07 /$ jam atau Rp. 2.370.988,7/jam.

Tabel 5. Hasil Optimasi Pada Blok 3

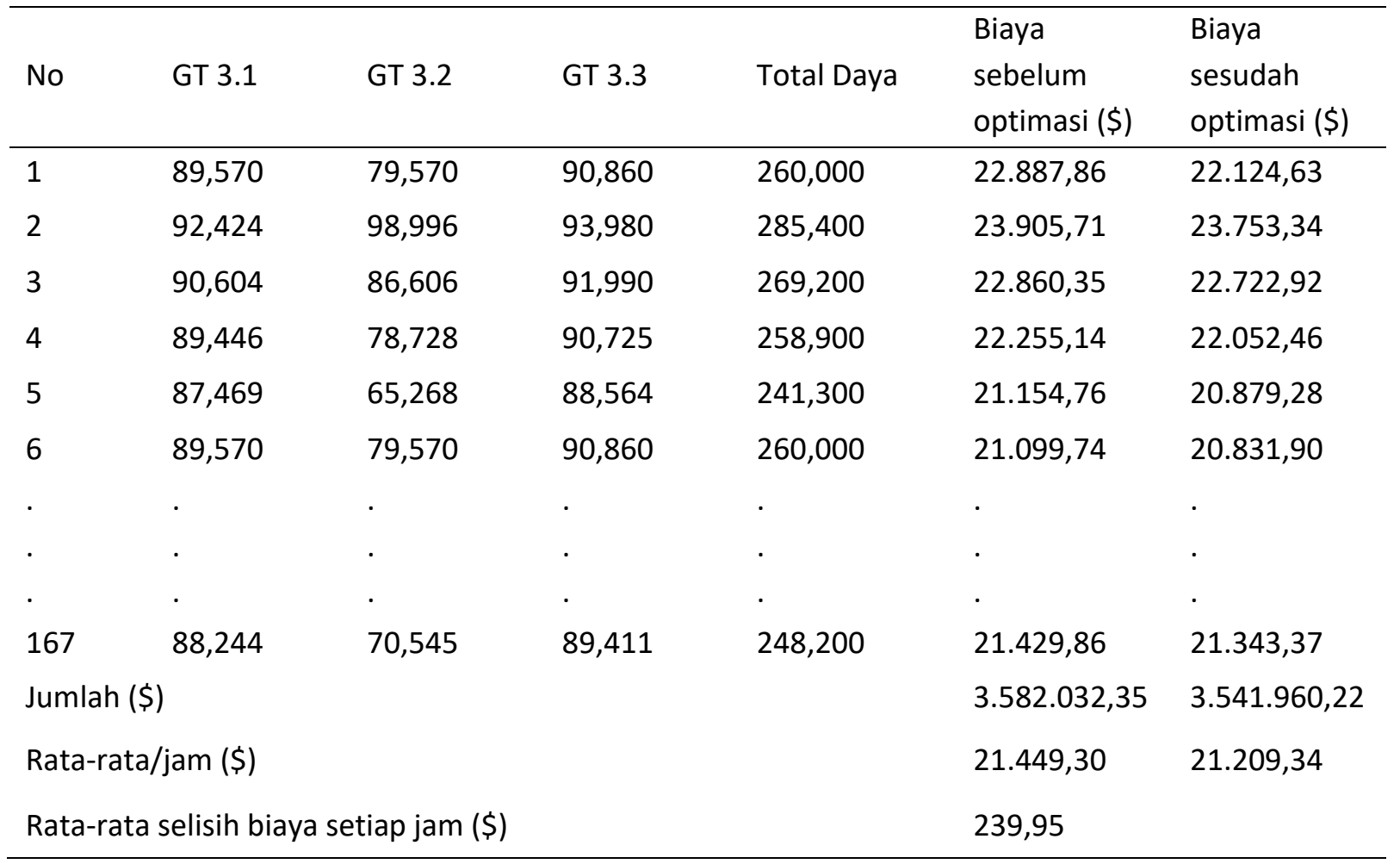

Tabel 5 menunjukan hasil optimasi dari blok 3, setelah dilakukan optimasi pembagian beban pada gas turbin diperoleh biaya yang lebih hemat dibandingkan dengan sebelum dilakukan optimasi. Dari hasil optimsi tersebut gas turbin 3.3 pada blok 3 lebih hemat dibandingkan dengan gas turbin lainnya. Rata-rata selisih biaya setiap jam pada blok 3 sebesar $\$ 239,95 /$ jam atau atau Rp. 3.385.015,16/jam. 
Tabel 6. Hasil Perbandingan

\begin{tabular}{llllllll}
\hline Blok & $\begin{array}{l}\text { Total biaya } \\
\text { sebelum } \\
\text { optimasi }(\$)\end{array}$ & $\begin{array}{l}\text { Total biaya } \\
\text { sesudah } \\
\text { optimasi }(\$)\end{array}$ & $\begin{array}{l}\text { Rata- } \\
\text { rata/jam } \\
\text { sebelum } \\
\text { optimasi }(\$)\end{array}$ & $\begin{array}{l}\text { Rata- } \\
\text { rata/jam } \\
\text { sesudah } \\
\text { optimasi }(\$)\end{array}$ & $\begin{array}{l}\text { Selisih } \\
\text { total biaya } \\
\text { operasi } \\
(\$)\end{array}$ & $\begin{array}{l}\text { Selisih } \\
\text { rata- } \\
\text { rata/jam } \\
(\$)\end{array}$ & $\begin{array}{l}\text { Selisih total } \\
\text { biaya operasi } \\
(\mathrm{Rp})\end{array}$ \\
\hline I & $3.648 .819,18$ & $3.620 .751,19$ & $21.849,22$ & $21.681,14$ & $28.067,99$ & 168,07 & $395.955 .074,64$ \\
III & $3.582 .032,35$ & $3.541 .960,22$ & $21.449,30$ & $21.209,34$ & $40.072,13$ & 239,95 & $565.297 .532,00$ \\
\hline
\end{tabular}

Tabel 6 menunjukkan perbadingan hasil optimasi dari blok 1 dan 3 dari segi biaya operasi per jam dan total biaya operasi dalam waktu satu minggu. Dari hasil tersebut blok 3 lebih hemat dibandingkan dengan blok 1. Biaya operasi yang dapat dihemat oleh blok 3 dalam waktu satu minggu sebesar Rp. 565.297.532,00 dan blok 1 sebesar Rp. 395.955.074,64.

\section{Kesimpulan}

Berdasarkan hasil optimasi pembagian beban pada data operasi bulan September 2018 di PT. PJB UP Gresik menggunakan iterasi lambda berdasarkan base point and participation factors, maka dapat disimpulkan bahwa pembagian beban pada gas turbin Blok 1 dan Blok 3 PLTGU PT. PJB UP Gresik yang lebih optimal yaitu GT 1.3 pada Blok 1 dan GT 3.3 pada Blok 3. Pada Blok 1, rata-rata daya yang dibangkitkan GT 1.3 95,449 MW. Sedangkan pada Blok 3, rata-rata daya yang mampu dibangkitkan GT $3.389,205 \mathrm{MW}$.

Berdasarkan hasil perhitungan, menyatakan bahwa Blok 3 lebih hemat dalam penggunaan bahan bakar dibandingkan Blok 1, dilihat dari selisih total biaya dan selisih rata-rata per jam. Blok 3 memiliki selisih biaya operasi sebelum optimasi dengan setelah optimasi lebih besar dibandingkan Blok 1 yaitu 239,95 \$/jam atau Rp. 3.385.015,16/jam dan total biaya selama 7 hari sebelum optimasi dan sesudah optimasi memiliki selisih sebesar 40.072,13 \$ atau Rp. 565.297.532. Sedangkan untuk Blok 1 rata-rata selisih biaya setiap jam pada Blok 1 adalah 168,07 \$/jam atau Rp. 2.370.988,7/jam dan total biaya selama 7 hari sebelum optimasi dan sesudah optimasi memiliki selisih sebesar $28.067,99 \$$ atau Rp. 395.955.074,64.

\section{Ucapan Terima Kasih}

Penulis mengucapkan terima kasih kepada semua pihak yang telah memberikan dukungan baik materil maupun moril sehingga penelitian ini dapat penulis selesaikan.

\section{Referensi}

[1] Eka Nandang Supriatna, "Penjadwalan Ekonomis Pembangkit Termal Dengan Memperhitungkan Rugi-Rugi Transmisi Menggunakan Pattern Search," Bandung, 2016.

[2] Bahtera Tambun, "Economic Dispatch PLTU Pangkalan Susu," Teknik Elektro, Fakultas Teknik, Medan, 2018.

[3] Marsudi Djiteng, Operasi Sitem Tenaga Listrik, Edisi Kedua. Yogyakarta: Graha Ilmu, 2006.

[4] Kartika Ika Putri, "Analisis Economic Dispatch Pembangkit Termal dengan Menggunakan Metode 
Iterasi Lambda pada Sistem Kelistrikan Sumbar ," Teknik Elektro, Fakultas Teknik, Padang, Skripsi 2017.

[5] Hana Nabila, "Analisi Economic Dispatch pada PLTU Sektor Bukit Asam Menggunakan Metode Iterasi Lambda dan Dynamic Programming," Teknik Elektro, Fakultas Teknik, Bandar Lampung, Skripsi 2017.

[6] Meisya Tiara Putri, "Analisa Performansi Perawatan pada Gas Turbin PLTGU Blok 1," Malang, 2018.

[7] Salam Sayeed, "Unit Commitment Solution Methods," World Academy of Science, Engineering and Technology, 2007.

[8] Bruce F and Alen J Wood, Power Generation, Operation, and Control, 2nd ed. New York: Jhon Willey \& Sons, INC, 2013. 